\title{
Manajemen Pasien Stroke Perdarahan Spontan dengan Komorbid Penyakit Paru Obstruktif Kronik yang Terjadi Bronkhospasme Intraoperasi
}

\author{
Radian Ahmad Halimi, Dewi Yulianti Bisri \\ Departemen Anestesiologi dan Terapi Intensif \\ Fakultas Kedokteran Universitas Padjadjaran Rumah Sakit Dr. Hasan Sadikin Bandung
}

\begin{abstract}
Abstrak
Stroke perdarahan spontan dan penyakit paru obstruktif kronik (chronic obstructive pulmonary disease/COPD) merupakan dua penyakit yang memiliki angka morbiditas dan mortalitas yang paling tinggi di dunia. Kondisi COPD akan meningkatkan resiko terjadinya stroke, selain itu dapat mengakibatkan terjadinya hipoksemia dan hiperkapnia. Seorang pria berusia 62 tahun datang ke unit gawat darurat karena mengalami penurunan kesadaran dan tidak dapat menggerakkan anggota tubuh sebelah kiri sejak 1 hari, pasien memiliki riwayat hipertensi namun tidak rutin meminum obat, pasien memiliki riwayat sering sesak, dan berdasarkan pemeriksaan fisik didapatkan kondisi barrel chest. Berdasarkan pemeriksaan CT-scan kepala didapatkan perdarahan intrakranial spontan pada basal ganglia sinistra. Pasien dilakukan tindakan kraniotomi evakuasi, namun 2 jam setelah dilakukan induksi anestesi terjadi kondisi desaturasi, hiperkapnia, peningkatan tekanan jalan nafas, dan ditemukan wheezing pada kedua lapang paru, kemudian diberikan terapi farmakologis dan non farmakologis untuk mengatasi kondisi bronkospasme. Pascabedah dilakukan pemanjangan ventilasi mekanik hingga pasien memenuhi kriteria untuk dilakukan ekstubasi. Penanganan pasien stroke dengan komorbid COPD membutuhkan pemahaman yang lebih mendalam mengenai interaksi otak dengan fungsi pernafasan akibat perubahan fisiologi dan patofisiologi pasien COPD.
\end{abstract}

Kata kunci: Bronkospasme, Penyakit paru obstruktif kronik, Stroke perdarahan spontan

JNI 2019;8 (2): 105-11

\section{Management of Spontaneous Intracranial haemorhage with Comorbids Chronic Obstructive Pulmonary Disease Occurring Intraoperative Bronchospasm}

\begin{abstract}
Stroke and chronic obstructive pulmonary disease (COPD) are the two diseases that have the highest morbidity and mortality rates in the world. COPD conditions will increase the risk of stroke, but it can lead to hypoxemia and hypercapnia. A 62-year-old man came to the emergency room because of a decreased consciousness and was unable to move the left limb since 1 day, the patient had a history of hypertension but did not regularly take medication, the patient had a history of frequent tightness, and based on physical examination was obtained barrel chest condition. Based on a head CT scan, spontaneous intracranial hemorrhage occurs in the left basal ganglia. Evacuation craniotomy was performed, but 2 hours after anesthesia induction occurred conditions of desaturation, hypercapnia, increased airway pressure, and wheezing was found in both lung fields, then given pharmacological and non-pharmacological therapy to overcome the condition of bronchospasm. After surgery, lengthening of mechanical ventilation is done until the patient meets the criteria for extubation. The treatment of stroke patients with co-morbid COPD requires a deeper understanding of brain interactions with respiratory function due to changes in physiology and pathophysiology of COPD patients.
\end{abstract}

Key words: Bronchospasm, chronic obstructive pulmonary disease, intracranial haemorrhage

JNI 2019;8 (2): 105-11 


\section{Pendahuluan}

Stroke dan penyakit paru obstruktif kronik merupakan dua penyakit yang memiliki angka morbiditas dan mortalitas yang paling tinggi di dunia. ${ }^{1}$ Kejadian stroke terdiri dari dua sub tipe, yakni stroke iskemik (terjadi 85-90\% kasus stroke) dan stroke akibat perdarahan intrakranial (10-15\%). Perdarahan intrakranial (intracranial haemorrhage/ICH) berdasarkan penyebabnya dibagi menjadi 2 yakni, ICH primer (spontan) dan ICH sekunder. Perdarahan intrakranial spontan diakibatkan oleh rupturnya arteri kecil dan arteriole yang rusak akibat kondisi hipertensi kronis $(60 \%)$, atau amyloid angiopati $(30 \%){ }^{2}$ Penyakit paru obstruktif kronik (chronic obstructive pulmonary disease/COPD) merupakan kondisi yang memiliki karakteristik adanya keterbatasan pada jalan nafas yang persisten, yang diasosiasikan dengan respons inflamasi abnormal di paru terhadap partikel atau gas, dan sering kali mengakibatkan efek pada sistemik dan/atau komorbiditas. Kondisi COPD dapat mengakibatkan terjadinya hipoksemia dan hypercapnia, yang dapat berakibat buruk terhadap kondisi otak yang mengalami kerusakan. ${ }^{1}$

\section{Kasus}

Anamnesa

Seorang pria berusia 62 tahun datang ke unit gawat darurat dengan penurunan kesadaran dan tidak dapat menggerakkan anggota tubuh sebelah kiri sejak 1 hari, pasien memiliki riwayat hipertensi namun tidak rutin meminum obat, pasien memiliki riwayat sering sesak yang tidak di pengaruhi aktifitas pasien riwayat merokok 3 bungkus perhari.

\section{Pemeriksaan Fisik}

Pemeriksaan fisik pasien dengan kesadaran Sopor (GCS E2M5V2) tekanan darah 190/100 $\mathrm{mmHg}$, nadi $98 \mathrm{x} /$ menit, respirasi $24 \mathrm{x} / \mathrm{menit}$, Saturasi $0_{2}$ $95 \%$, pada pemeriksaan mata didapatkan pupil anisokor, pada pemeriksaan thorax didapatkan kondisi barrel chest.

\section{Pemeriksaan Penunjang}

Laboratorium didapatkan Leukositosis (22.480) hasil kimia klinik dan AGD dalam batas
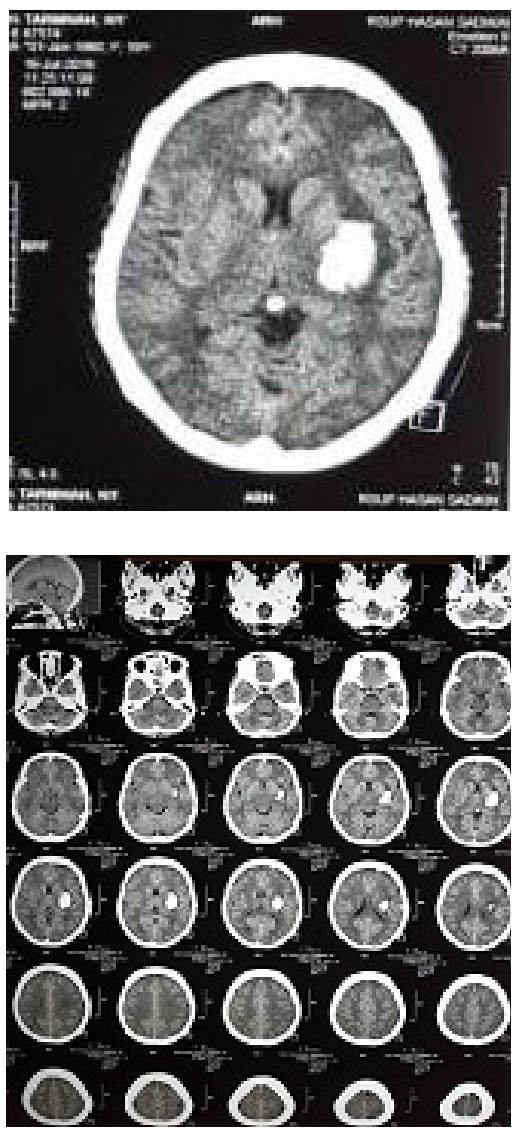

Pemeriksaan CT-scan Kepala

normal, Pada pemeriksaan thorax didapatkan Kardiomegali tanpa bendungan paru dan pada pemeriksaan CT-scan kepala didapatkan perdarahan intrakranial spontan pada basal ganglia sinistra dan terdapt midline shift $>5 \mathrm{~mm}$.

\section{Pengelolaan Anestesi}

Persiapan preoperatif dilakukan regulasi tekanan darah dengan perdipine dengan target tekanan darah sistolik $160 \mathrm{mmHg}$, head up $30 \mathrm{o}$, diberikan suplementasi oksigen dengan kanula nasal 31pm, cairan rumatan dengan ringer fundin $100 \mathrm{cc} / \mathrm{jam}$, puasa dilanjutkan, persiapan ruangan ICU untuk perawatan paskabedah dengan ventilator, persiapan darah 2 packed red cell (PRC) dan 2 fresh frozen plasma (FFP). Pemeriksaan pre induksi didapatkan kesadaran GCS 9 E2M5V2, tekanan darah 145/93 $\mathrm{mmHg}$ dengan perdipin $0,3 \mathrm{mcg} / \mathrm{kg} / \mathrm{menit}$, nadi 91 kali per menit, laju nafas 20 kali per menit, $\mathrm{SpO}_{2} 97 \%$ dengan kanula nasal $3 \mathrm{lpm}$. Induksi dilakukan dengan fentanil $200 \mathrm{mcg}$, 
propofol $160 \mathrm{mg}$, lidokain $120 \mathrm{mg}$ rokuronium $60 \mathrm{mg}$, sebelum intubasi diberikan propofol tambahan $80 \mathrm{mg}$. Dilakukan intubasi dengan endotracheal tube (ETT) No. 7.5. Maintenance anestesi dengan propofol $100-200 \mathrm{mcg} / \mathrm{kg} / \mathrm{mnt}$. $\mathrm{O}_{2}$ dan udara $=3: 3$.

Pasien dilakukan tindakan kraniotomi evakuasi, namun 2 jam setelah dilakukan induksi anestesi terjadi kondisi desaturasi, hiperkapnia, peningkatan tekanan jalan nafas, dan ditemukan wheezing padakedualapang paru, penatalaksanaan saat itu dilakukan pemberian propofol bolus intravena $160 \mathrm{mg}$, rumatan anestesi ditambahkan sevoflurane 1-2 vol\%, $\mathrm{FiO}_{2}$ dinaikkan hingga 100\%, diberikan aminophilin Loading dose: 480 $\mathrm{mg}$ dalam 20 menit dan Maintenance: $40 \mathrm{mg} / \mathrm{jam}$. Operasi dilanjutkan, selama operasi berlangsung didapatkan tekanan darah sistolik pasien berkisar 128-155mmHg, tekanan darah sistolik 110-128 mmhg, saturasi $0^{2} 85-92 \%$, EtCO $24-52 \mathrm{mmHg}$. Operasi berlangsung selama 4 jam 30 menit dengan perdarahan $500 \mathrm{cc}$ dan diuresis $100 \mathrm{cc} /$ jam. Intraoperasi ditemukan ICH clot $40 \mathrm{cc}$ $+10 \mathrm{cc}$, duramater dijahit kembali dan tulang di pasang kembali.

\section{Penngelolaan Pascabedah}

Dilakukan pemanjangan ventilasi mekanik dengan di sedasi menggunakan propofol $50-100 \mathrm{mcg} / \mathrm{kg} / \mathrm{menit}$, tekanan darah $143 / 88$ $\mathrm{mmHg}$ tanpa support, menggunakan ventilator dengan mode SIMV PS; Vt:640;RR 16x/m; PS 10; PEEP:10, Rasio I:E = 1:2,5, saturasi $\mathrm{O}_{2}$ 90\% dengan $\mathrm{FiO}_{2} 80 \%$, pemeriksaan fisik ditemukan wheezing $(+)$ di kedua lapang paru. Sedasi dilanjutkan, obat analgesik pascabedah dengan fentanil $20 \mathrm{mcg} / \mathrm{jam}$ dikombinasi dengan paracetamol 4x1 gram IV, elevasi kepala $30^{\circ}$, Proteksi lambung dengan omeprazole $2 \times 50 \mathrm{mg}$, Test feeding bila bising usus (+)N, antibiotik dengan ceftriakson, nebulisasi dengan combivent, dilakukan pemberian N-Acetylcysteine, serta profilaksis kejang dengan phenytoin.

Pascabedah hari pertama didapatkan pemeriksaan kesadaran GCS E3M5Vt (GCS 8T) dengan tekanan darah 153/76 mmHg, nadi 70-92 x/menit, fungsi respirasi pasien on ventilator mode PS: 8;
PEEP: 8; $\mathrm{FiO}_{2}: 50 \%, \mathrm{SpO}_{2}$ 96\%. Berdasarkan pemeriksaan fisik didapatkan bunyi paru wheezing berkurang. Hasil pemeriksaan lab $\mathrm{Hb}$ 11.2, Ht 34, Leukosit 14.000, Trombosit 192.000, $\mathrm{Na} 137$, Kal 3.9, $\mathrm{pH} 7.35, \mathrm{pCO}_{2} 45, \mathrm{pO}_{2} 76, \mathrm{HCO}_{3}$ $32, \mathrm{BE} 4, \mathrm{SpO}_{2} 95 \%$. Sedasi dan analgesik diganti dengan menggunakan dexmedetomidine $0,1 \mathrm{mcg} /$ $\mathrm{kg} / \mathrm{jam}$, yang dikombinasi dengan paracetamol, pemberian nutrisi menggunakan Peptamen.

Pascabedah hari kedua didapatkan kesadaran GCS E4M5Vt (GCS 9T) dengan tekanan darah 150/80 mmHg, nadi 60-75 x/menit, Respirasi on ventilator mode PS: 0; PEEP: 4; $\mathrm{FiO}_{2}: 35 \%$, $\mathrm{SpO}_{2}$ 97\%. Pemeriksaan fisik tidak didapatkan wheezing. terapi antihipertensi diberikan secara peroral menggunakan amlodipin 1x10 mg, captopril 2 x 12,5 mg. Pasien dilakukan ekstubasi

Tabel 1. ICH Score

\begin{tabular}{|c|c|}
\hline Component & ICH Score Points \\
\hline \multicolumn{2}{|l|}{ GCS score } \\
\hline $3-4$ & 2 \\
\hline $5-12$ & 1 \\
\hline $13-15$ & 0 \\
\hline \multicolumn{2}{|l|}{$\mathrm{ICH}$ volume $\left(\mathrm{cm}^{30}\right)$} \\
\hline$\geq 30$ & 1 \\
\hline$<30$ & 0 \\
\hline \multicolumn{2}{|l|}{ IVH } \\
\hline Yes & 1 \\
\hline No & 0 \\
\hline \multicolumn{2}{|l|}{$\begin{array}{c}\text { Infratentorial origin } \\
\text { of } \mathrm{ICH}\end{array}$} \\
\hline Yes & 1 \\
\hline No & 0 \\
\hline \multicolumn{2}{|l|}{ Age (year) } \\
\hline$\geq 80$ & 1 \\
\hline$<80$ & 0 \\
\hline Total ICH Score & $0-6$ \\
\hline
\end{tabular}

Dikutip dari: www.mdcalc.com

dan pemberian noninvasive ventilation (NIV) pascaekstubasi. Pascabedah hari perawatan ketiga didapatkan kesadaran GCS E4M5Vafasia dengan tekanan darah 146/75 mmHg, nadi 55-73 x/ menit, respirasi 12-14 x/menit $\mathrm{SpO}_{2} 97 \%$ dengan kanula binasal $3 \mathrm{lpm}$ pada Pemeriksaan fisik tidak 
didapatkan wheezing, pasien direncanakan untuk pindah ke ruangan.

\section{Pembahasan}

Perdarahan intrakranial spontan (intracranial haemorrhage/ $\mathrm{ICH}$ ) nontraumatic merupakan sub tipe stroke kedua yang paling sering terjadi dan diasosiasikan dengan angka kejadian mortalitas dan morbiditas yang tinggi di seluruh dunia. ${ }^{3}$ Perdarahan intrakranial spontan diakibatkan oleh rupturnya arteri kecil dan arteriole yang rusak akibat kondisi hipertensi kronis $(60 \%)$, atau amyloid angiopati (30\%). ${ }^{2}$ Patogenesis terjadinya ICH spontan diakibatkan oleh pecahnya pembuluh darah arteri intracerebral, dan kegawatan yang fatal biasanya terjadi pada 2 hari pertama saat onset ICH terjadi. Sebanyak $20 \%$ pasien dengan ICH spontan terjadi penurunan fungsi neurologis pada periode sebelum masuk ke rumah sakit, dan $25 \%$ pasien terjadi penurunan fungsi neurologis pada periode saat di rumah sakit. Evaluasi, diagnosis dan penanganan yang terkonsentrasi merupakan hal yang sangat krusial pada terapi inisial pasien dengan ICH spontan. Ketika pasien datang dengan defisit neurologis fokal, nyeri kepala hebat, muntah, tekanan darah sistolik $>220 \mathrm{mmHg}$, dan terjadi penurunan kesadaran dengan onset yang cepat, diagnosis yang perlu dipertimbangkan pertama kali adalah ICH. Data lain yang perlu didapatkan pada pasien dengan gejala klinis tersebut adalah riwayat penyakit hipertensi, stroke sebelumnya, kejadian trauma kepala dalam waktu dekat, dan penggunaan obat-obatan antikoagulan dan antitrombotik. ${ }^{3}$ Selain insial diagnosis saat berada di ruang gawat darurat, manajemen secara cepat perlu dilakukan secara simultan. Manajemen yang dilakukan diantaranya adalah manajemen jalan nafas, penyokong kardiovaskular, terapi kontrol tekanan darah secara cepat, dan mengkoreksi abnormalitas faktor koagulasi. Saat ini telah digunakan suatu skala untuk memprediksi prognosis pada pasien dengan ICH spontan. Sistem ICH score biasa digunakan untuk menilai prognosis pasien dengan ICH spontan, dan sistem skoring ini mudah digunakan dengan menilai pemeriksaan neurologis dan CT-scan. ${ }^{3}$
Berdasarkan anamnesis pada pasien ini didapatkan tanda penurunan kesadaran pada 1 hari sebelum masuk rumah sakit, dan didapatkan gejala defisit neurologis pada tubuh bagian kiri. Berdasarkan anamnesis didapatkan riwayat sesak namun aktifitas sehari-hari masih baik, dan pasien biasa merokok hingga 3 bungkus dalam 1 hari. Pasien memiliki riwayat hipertensi namun tidak meminum obat secara rutin dan tidak memiliki riwayat konsumsi obat pengencer darah secara rutin. Berdasarkan sistem penilaian "ICH score", pasien ini didapatkan nilai 2, yang interpertasinnya menunjukkan bahwa angka mortalitas pada pasien ini adalah $26 \%$. Berdasarkan pemeriksaan fisik didapatkan kondisi peningkatan tekanan darah hingga 190/100 mmhg dan saat itu dilakukan regulasi tekanan darah menggunakan perdipine dengan target penurunan tekanan darah hingga $20 \%$.

Berdasarkan pemeriksaan fisik didapatkan tanda barrel chest dan peningkatan laju nafas, namun pada pasien ini tidak didapatkan tanda wheezing pada pemeriksaan fisik preoperasi. Berdasarkan pemeriksaanlaboratorium didapatkan peningkatan nilai tekanan $\mathrm{CO}_{2}$ arteri namun tidak diikuti oleh peningkatan $\mathrm{pH}$ dan $\mathrm{HCO}_{3}$, yang menandakan bahwa telah terjadi proses adaptasi yang lama. Berdasarkan pemeriksaan klinis dan penunjang tersebut, maka pasien ini kami diagnosa dengan COPD. Diagnosis COPD seharusnya dilakukan menggunakan alat spirometry dengan menghitung $\mathrm{FEV} 1 / \mathrm{FVC}<0,7$, yang diperiksa saat prebronchodilator, namun apabila tidak memiliki alat spirometry maka diagnosis dilakukan berdasarkan informasi daristatus pasien dan klinisi ahli paru. ${ }^{1}$ Kondisi COPD akan meningkatkan resiko terjadinya stroke, baik stroke iskemik maupun perdarahan. Kondisi stroke itu sendiri dapat mengakibatkan terjadinya komplikasi disfungsi sistem pernafasan, yakni terganggunya fungsi batuk (mekanisme pertahanan jalan nafas), dan terjadinya kelemahan otot-otot pernafasan, yang mengakibatkan terjadinya infeksi paru (pneumonia). Sehingga kondisi stroke yang diakibatkan atau memiliki komorbiditas COPD, dapat meningkatkan angka morbiditas dan mortalitas pasien. 
Berdasarkan suatu penelitian menyatakan bahwa resiko terjadinya stroke akan meningkat $20-30 \%$ pada pasien dengan COPD dibandingkan dengan pasien non-COPD. Berdasarkan suatu penelitian menyatakan bahwa kondisi COPD memiliki reiko lebih tinggi untuk terjadinya kerusakan pembuluh darah besar dan pembuluh darah kecil. $^{4-6}$ Faktor resiko utama yang menyebabkan terjadinya kondisi COPD dan stroke adalah riwayat merokok, karena berdasarkan penelitian sebelumnya menyatakan bahwa rokok menyebabkan terjadinya perubahan anatomis pada jaringan paru, kerusakan dinding pembuluh darah (penebalan tunika media) dan jaringan otak (yang dilihat berdasarkan pemeriksaan magnetic resonance imaging (MRI)). ${ }^{1,4,6}$ Saat 2 jam setelah dilakukannya induksi anestesi, terjadi kondisi desaturasi, peningkatan $\mathrm{ETCO}_{2}$, peningkatan peak pressure, dan berdasarkan pemeriksaan auskultasi paru didapatkan wheezing pada kedua lapang paru. Sehingga penilaian saat itu adalah terjadi kondisi bronchospasme. Tindakan yang dilakukan saat itu adalah dilakukan pengecekan terhadap pipa endotracheal dan breathing circuit. Dilakukan bolus propofol intravena dan menambahkan sevoflurane $1-2$ vol\% untuk rumatan anestesi, meningkatkan rasio inspirasi ekspirasi menjadi 1;3, meningkatkan positive end expiratory pressure (PEEP) menjadi 10 mmHg, meningkatkan $\mathrm{FiO}_{2}$ hingga $100 \%$, dan memberikan aminophilin. Setelah saturasi oksigen meningkat hingga $90 \%$ dan $\mathrm{ETCO}_{2}$ menurun hingga $55 \mathrm{mmHg}$, tindakan operasi dilanjutkan kembali. Saat dilakukan pembukaan periosteum dilakukan pemberian mannitol $1 \mathrm{gr} / \mathrm{kg}$.

Intraoperasi otak tidak tampak tegang, dan setelah dilakukan evakuasi, tulang kepala kembali dipasang. Pascabedah dilakukan pemanjangan ventilasi mekanik, karena masih ditemukan wheezing pada kedua lapang paru. Postoperative pulmonary complication (PPC) merupakan komplikasi pascabedah kraniotomi, dengan angka kejadiannya sebesar 23\%. Komplikasi PPC ini biasanya berupa kondisi bronkopneumonia, atelektasis, bronkospasme, gagal nafas, dan lain-lain. Resiko terjadinya PPC akan meningkat pada pasien dengan peningkatan usia (>60 tahun), klasifikasi American Society of
Anaesthesiologist (ASA) $\geq 2$, pasien dalam kondisi vegetatif, memiliki komorbid COPD sebelumnya, dan penyakit jantung kongestif. Prinsip utama penanganan terjadinya komplikasi paru adalah mencegah, mengatasi, mengoptimalisasi kondisi hipoksemia dan mejaga keseimbangan oksigen untuk mencegah terjadinya cedera otak sekunder. Untuk menjaga keseimbangan oksigen dapat dilakukan dengan melakukan terapi farmakologis dan non-farmakologis. ${ }^{7,8}$

Terapi non farmakologis untuk menjaga keseimbangan oksigen pada kasus ini adalah menjaga saturasi oksigen $\geq 90 \%$, atau $\mathrm{PaO}_{2} \geq 60$ $\mathrm{mmHg}$. Hal tersebut dapat dilakukan dengan memberikan oksigen $100 \%$ hingga pasien dipastikan telah mendapat oksigen yang adekuat. Berdasarkan suatu literatur menyatakan bahwa pemberian positive end expiratory pressure (PEEP) dapat meningkatkan tekanan intrakranial (TIK) pada pasien dengan kerusakan atau gangguan di otak, karena dapat meningkatkan volume vena serebral dengan menurunkan aliran darah vena di otak. Namun berdasarkan beberapa penelitian menyatakan bahwa pemberian PEEP $10 \mathrm{cmH} 20$ dapat meningkatkan oksigenasi dan secara klinis tidak selalu meningkatkan TIK pada pasien dengan cedera kepala berat. PEEP akan lebih kecil mempengaruhi TIK pada pasien yang memiliki paru yang kaku (pasien dengan COPD), dimana pasien tersebut memang membutuhkan PEEP untuk menjaga oksigenasi. ${ }^{9}$ Secara teori, PEEP dapat mempengaruhi TIK dengan cara meningkatkan tekanan pleura dan menurunkan aliran balik vena (venous return). Transmisi PEEP menuju rongga thoraks sangat dipengaruhi oleh paru dan dinding dada.

Suatu penelitian menyatakan bahwa semakin tinggi tingkat elastisitas dinding dada, maka PEEP secara signifikan dapat meningkatkan tekanan pada pleura sehingga akan meningkatkan TIK. Elastisitas paru secara umum diketahui akan meningkat pada pasien dengan acute respiratory distress syndrome (ARDS) karena terjadi alveoli yang kolaps dalam jumlah yang banyak. Tekanan PEEP memiliki pengaruh yang lebih besar pada pasien dengan rasio elastisitas dinding dada (rasio antara dinding dada dengan sistem pernafasan) 
yang tinggi (elastisitas paru yang rendah atau elastisitas dinding dada yang tinggi). ${ }^{10}$ Pasien dengan COPD memiliki elastisitas paru yang tinggi akibat lebih banyak ruang di alveoli paru, sehingga akan memiliki rasio elastisitas dinding dada yang rendah. Rasio elastisitas dinding dada yang rendah akan menyebabkan pemberian PEEP tidak akan terlalu berpengaruh terhadap peningkatan TIK. ${ }^{11}$ Sehingga pemberian PEEP pada pasien ini lebih memberikan manfaat (mencegah hipoksemia) dibandingkan terjadinya resiko peningkatan TIK.

Terapi farmakologis untuk mengatasi kondisi bronkospasme adalah dengan diberikannya obat bronkodilator, pada pasien ini diberikan terapi bronkodilator menggunakan sevoflurane. Berdasarkan beberapa penelitian dan literatur menyatakan bahwa gas sevoflurane memiliki efek bronkodilator untuk mengatasi kondisi bronkospasme dan asma eksaserbasi akut. Sevoflurane menyebabkan dilatasi pada distal jalan nafas dan alveolus, sehingga meminimalisir terjadinya kolaps pada alveoli dan semakin sedikitnya distorsi pada jaringan parenkim sekitarnya, yang akan menyebabkan berkurangnya adaptasi stress viskoelastik dan inhomogenitas. Mekanisme terjadinya dilatasi jalan nafas oleh sevoflurane adalah dengan menurunkan kalsium intraseluler pada otot polos jalan nafas. ${ }^{12}$ Terapi farmakologis lainnya untuk mengatasi kondisi bronkospasme adalah dilakukannya pemberian aminophiline intravena dan nebulisasi menggunakan combiven. Aminophiline dan combiven merupakan obat yang bekerja pada reseptor beta 2 agonis, sehingga memiliki efek brokodilator. Aminophiline dan combiven merupakan terapi lini pertama pada pasien dengan kondisi bronkospasme. ${ }^{13}$

Pasien ini diberikan propofol intravena untuk menurunkan cerebral metabolic rate $\left(\mathrm{CMRO}_{2}\right)$, untuk menjaga keseimbangan oksigen agar meminimalisir terjadinya kondisi cedera otak sekunder saat dalam kondisi hipoksemia. Tindakan ekstubasi dilakukan setelah parameter AGD menunjukkan nilai rasio $\mathrm{PaO}_{2} / \mathrm{FiO}_{2}>200$ pada $\mathrm{PEEP}<4 \mathrm{cmH} 20$, secara hemodinamik stabil tanpa vasopressor, respons fungsi neurologis telah adekuat, pasien dapat batuk dan mengeluarkan dahak, rapid shallow breathing index (RSBI) $<$ 100 setelah 2 menit spontaneous breathing trial (SBT). Pascaekstubasi sebaiknya dilakukan pemberian ventilasi mekanik menggunakan NIV. ${ }^{14}$

\section{Simpulan}

Penanganan pasien stroke dengan komorbid COPD membutuhkan pemahaman yang lebih mendalam mengenai interaksi otak dengan fungsi pernafasan akibat perubahan fisiologi dan patofisiologi pasien COPD.

\section{Daftar Pustaka}

1. Portegies MLP, Lahousse L, Joos GF, Hofman A, Koudstaal PJ, Stricker BH, dkk. Chronic obstructive pulmonary disease and the risk of stroke. American Journal Respiratory Critical Care Medicine. 2016;193(3): 251-8.

2. Mack PF. Intracranial haemorrhage: therapeutic interventions and anaesthetic management. Br J Anaesth. 2014; 113:17-25.

3. Kim JY, Bae HJ. Spontaneus intracerebral haemorrhage: Management. Journal of Stroke. 2017; 19(1): 28-39.

4. Kim YR, Hwang IC, Lee YJ, Ham EB, Park DK, Kim S. Stroke risk among patients with chronic obstructive pulmonary disease: a systematic review and meta analysis. Clinics. 2018;73(177):1-7

5. Lahousse L, Bouwhuijsen QJAV, Loth DW, Joos GF, Hofman A, Witteman JCM,dkk. Chronic obstructive pulmonary disease and lipid core carotid artery palques in the elderly. American Journal Respiratory Critical Care Medicine. 2013; 187:58-64.

6. Gestel YRBM, Flu WJ, Kuijk JPV, Hoeks SE, Bax JJ, Sin DD,dkk. Association of COPD with carotid wall intima media thickness in vascular surgery patients. Respiratory Medicine. 2010;104: 712-6. 
7. Early postoperative respiratory complications following elective craniotomies. Journal of Neuroanaesthesiology and Critical Care. 2015; 2(2): 85-7.

8. Lee K, Rincon F. Pulmonary complications in patients with severe brain injury. Critical Care Research and Practice. 2012; 1-8.

9. Rozet I, Domino KB. Care of the acutely unstable patient. Dalam: Cottrell JE, Young WL, editors. 2010 Neuroanaesthesia. 5th ed. Philadelphia: Elsevier; 2010. 161-83.

10. Zhang X, Yang Z, Wang Q, Fan H. Impact of positive end expiratory pressure on cerebral injury patients with hypoxemia. The American Journal of Emergency Medicine. 201. 29(7):699-703.

11. Copot D, Keyser RD, Derom E, Lonescu C.
Structural changes in the COPD lung and related heterogeneity. PLoS ONE. 2017; 12(5): $1-21$

12. Sorour K, Vyas PA, Raval DS, Donovan LM, Vyas AA. Succesful treatment of severe asthma exacerbation with sevoflurane inhalation in the intensive care unit. J Anesthesiology Critical Care Open Access. 2015; 3(2):1-3.

13. Looseley A. Management of bronchospasm during general anaesthesia. Update in Anaesthesia. 2011; 17-21.

14. Oshima T, Satoh T, Karasawa F. Effect of propofol on cerebral blood flow and the metabolic rate of oxygen in humans. Acta Anaesthesiologica Scandinavica. 2002; 46(7): 831-5. 